\title{
WT1 Peptide Cancer Vaccine for Patients with Hematopoietic Malignancies and Solid Cancers
}

\author{
Yoshihiro Oka ${ }^{1,2 *}$, Akihiro Tsuboi ${ }^{2}$, Olga A. Elisseeva ${ }^{3}$, \\ Hiroko Nakajima ${ }^{3}$, Fumihiro Fujiki ${ }^{3}$, Manabu Kawakami ${ }^{2}$, \\ Toshiaki Shirakata ${ }^{3}$, Sumiyuki Nishida ${ }^{2}$, Naoki Hosen ${ }^{3}$, \\ Yusuke Oji ${ }^{3}$, Ichiro Kawase ${ }^{1}$, and Haruo Sugiyama ${ }^{3}$ \\ Departments of ${ }^{1}$ Respiratory Medicine, Allergy and Rheumatic Diseases, ${ }^{2}$ Cancer \\ Immunotherapy, and ${ }^{3}$ Functional Diagnostic Science, Osaka University Graduate \\ School of Medicine, Japan \\ E-mail: yoshi@imed3.med.osaka-u.ac.jp
}

Received December 27, 2006; Revised April 9, 2007; Accepted April 11, 2007; Published May 29, 2007

Wild-type Wilms' tumor gene WT1 is expressed at a high level in hematopoietic malignancies including acute leukemia, chronic myelogenous leukemia, and myelodysplastic syndromes, as well as in various kinds of solid cancers. Human cytotoxic T lymphocytes (CTLs), which could specifically lyse WT1-expressing tumor cells with HLA class I restriction, were generated in vitro. It was also demonstrated that mice immunized with the WT1 peptide rejected challenges by WT1-expressing cancer cells and survived with no signs of autoaggression to normal organs that physiologically expressed WT1. Furthermore, we and others detected IgM and IgG WT1 antibodies in patients with hematopoietic malignancies, indicating that the WT1 protein was highly immunogenic, and that immunoglobulin class-switch-inducing, WT1-specific, cellular immune responses were elicited in these patients. $\mathrm{CD8}^{+}$WT1-specific CTLs were also detected in peripheral blood or tumor-draining lymph nodes of cancer patients. These results provided us with the rationale for elicitation of CTL responses targeting the WT1 product for cancer immunotherapy. On the basis of these findings, we performed a phase I clinical trial of a WT1 peptide cancer vaccine for the patients with malignant neoplasms. These results strongly suggested that the WT1 peptide cancer vaccine had efficacy in the clinical setting because clinical responses, including reduction of leukemic blast cells or regression of tumor masses, were observed after the WT1 vaccination in patients with hematopoietic malignancies or solid cancers. The power of a tumor-associated-antigen (TAA)-derived cancer vaccine may be enhanced in combination with stronger adjuvants, helper peptide, molecular-target-based drugs, or some chemotherapy drugs, such as gemcitabine, which has been revealed to suppress regulartory T-cell function. In contrast, reduction of WT1 peptide dose may be needed for the treatment of patients with hematological stem cell diseases, because rapid and strong destruction of malignant cell-sustained hematopoiesis before recovery of normal hematopoiesis may lead to pancytopenia in these patients.

KEYWORDS: WT1, cancer, immunotherapy, vaccine, clinical trial 


\title{
INTRODUCTION
}

Despite recent progress in surgical, chemotherapeutic, and radiotherapeutic approaches, cancer is still one of the diseases that is difficult to treat and cure, especially in patients with advanced stages of the disease. Therefore, new therapeutic strategies are required. One of the recent developments in this cancer treatment field is immunotherapy that targets tumor-associated antigens (TAAs).

WT1, Wilms' tumor gene, was isolated as a gene responsible for tumorigenesis of a childhood renal neoplasm, Wilms' tumor[1,2]. This gene encodes a zinc finger transcription factor involved in the regulation of cell proliferation and differentiation, in apoptosis, and in organ development $[3,4,5,6,7]$. The WT1 gene was categorized at first as a tumor-suppressor gene on the basis of the findings, such as intragenic deletions or mutations in Wilms' tumor, germline mutations in patients with leukemic predisposition syndromes, and WT1-mediated growth suppression of Wilms' tumor cells. However, we recently proposed that the wild-type WT1 gene performs an oncogenic rather than a tumor-suppressor function in leukemogenesis and tumorigenesis in various types of solid cancers, based on the following accumulated evidence: (1) high expression levels of the wild-type WT1 gene in various kinds of human malignant neoplasms including hematopoietic malignancies, such as leukemia and myelodysplastic syndromes (MDS), and solid cancers[8,910,11,12,13,14,15,16,17,18,19,20,21,22,23,24,25] (Table 1) (as far as we have determined, there are no qualitative differences such as point mutations in WT1 genes between tumor cells and normal cells); (2) growth inhibition of human leukemic or solid cancer cells by the treatment with WT1 antisense oligonucleotides[17,26]; and (3) growth promotion and differentiation block of murine myeloid progenitor cells by constitutive expression of wild-type WT1 gene[27,28].

\section{TABLE 1}

WT1-Expressing Malignancies

\author{
Hematopoietic malignant disorders \\ Acute myeloid leukemia (AML) \\ Acute lymphocytic leukemia (ALL) \\ Chronic myelogenous leukemia (CML) \\ Myelodysplastic syndromes (MDS) \\ Non-Hodgkin lymphoma (NHL) ${ }^{\mathrm{a}}$ \\ Multiple myeloma (MM) ${ }^{\mathrm{b}}$ \\ Solid cancers \\ Lung cancer \\ Breast cancer \\ Head and neck squamous cell carcinoma \\ Bone and soft-tissue sarcoma \\ Thyroid cancer \\ Esophageal cancer \\ Colorectal adenocarcinoma \\ Pancreatic ductal adenocarcinoma \\ Primary astrocytic tumors \\ a Expression of WT1 in NHL cells was very \\ recently demonstrated. See text for details. \\ b Although WT1 expression level in MM is not \\ so high, MM cells are very susceptible to \\ WT1-specific CTLs. See text for details.
}


$\mathrm{CD}^{+}$cytotoxic $\mathrm{T}$ lymphocytes (CTLs) are the most important effector cells for antitumor immune responses, and they recognize TAA-derived peptides that are "processed" and presented on the tumor cell surface in association with major histocompatibility complex (MHC) class I molecules, leading to the killing of the tumor cells[29,30]. Clinical evidence for the effectiveness of antitumor immune responses has been obtained in several clinical settings, including graft-vs.-leukemia (GVL) effect after allogeneic hematopoietic stem cell transplantation[31].

Taken together, these findings strongly suggested that the WT1 protein might be a promising target antigen for cancer immunotherapy against hematopoietic malignancies as well as various kinds of solid cancers[32,33]. Tumor escape from immune surveillance as a result of down-regulation of WT1 expression is unlikely to occur[32,33] because expression of WT1 at a high level seems to have an essential role in leukemogenesis or tumorigenesis, and seems to be required to maintain the transformed phenotype[17,26,27,28]. This is a theoretical advantage for using an oncogenic function-bearing protein like the WT1 product as a target antigen for cancer immunotherapy.

In this article, we will review recent investigations, including ours and those of other groups, aiming at the development of cancer immunotherapy targeting the Wilms' tumor gene WT1 product. Furthermore, since we have performed a phase I clinical study of a WT1 peptide cancer vaccine, and observed clinical responses in some cases after the vaccination, we will also summarize the result with discussion about other groups' clinical study result, and briefly describe the clinical courses of some of the clinical response-positive patients. Finally, we will describe a perspective for cancer immunotherapy, particularly peptide cancer vaccine.

\section{IN VITRO GENERATION AND CHARACTERIZATION OF HUMAN WT1-SPECIFIC CTLS}

\section{Identification of HLA Class I-Restricted CTL Epitopes of WT1}

Several groups, including ours, succeeded in the generation of human WT1-specific CTLs (Table 2). We identified Db126 (RMFPNAPYL, also called WT126: underlined letters represent anchor-motifs for HLA-A*0201) and WH187 (SLGEQQYSE) as epitopes that could induce WT1-specific CTLs with the restriction of HLA-A*0201, which was the most frequent HLA class I type in Caucasians and also frequent in Japanese[32,34,35]. This result was confirmed by another group that used a unique "allorestricted CTL approach" to generate the WT1-specific CTLs[36]. This approach seems to be very useful to circumvent immunologic tolerance to TAAs that are mostly self-proteins[36]. WT235 (CMTWNQMNL, originally called WT1-T2; an underlined letter represents an anchor-motif for HLA$\left.A^{*} 2402\right)$ was identified as an epitope that could induce WT1-specific CTLs with the restriction of HLAA*2402, which was the most frequent HLA class I type in Japanese and also frequent in Caucasians[37,38]. It was recently demonstrated that the WT235 peptide could induce not only HLAA*2402, but also HLA-A*0201-restricted, WT1-specific CTLs[39,40]. A new HLA-A*2402-restricted CTL epitope, RWPSCQKKF (F at position 9 is an anchor-motif for HLA-A*2402), was also identified recently[41].

The CTLs that were generated from peripheral blood T cells by stimulation with the WT1 peptides killed endogenously WT1-expressing tumor cells including leukemia and solid cancer cells[32,34,35, $36,37,38,39,40,41,42,43]$, indicating that the epitope peptides were "processed" from the WT1 protein in the tumor cells, followed by the presentation on the cell surface in association with HLA class I molecules to be recognized by the CTLs.

All the CTL epitopes listed in Table 2 had a common structure in that they had at least one anchor residue for the peptide-binding HLA class I molecules, as described in the first part in this chapter. It would be very useful if we could predict the strength of the antitumor effect of each peptide as a cancer vaccine. However, it is impossible at this moment to predict the strength according to the sequences. Furthermore, it is difficult to compare the immunogenic ability of the peptides identified as CTL epitopes 
TABLE 2

CTL Epitopes that can Elicit WT1-Specific CTLS

\author{
HLA-A*0201 restriction \\ RMFPNAPYL \\ SLGEQQYSV \\ CMTWNQMNL ${ }^{\mathrm{a}}$ \\ HLA-A ${ }^{\star} 2402$ restriction \\ CMTWNQMNL ${ }^{\mathrm{a}}$ \\ CYTWNQMNL $^{\mathrm{b}}$ \\ RWPSCQKKF \\ a This peptide was revealed to elicit WT1-specific CTLs with \\ restriction of both HLA-A*0201 and HLA-A*2402. \\ b This peptide is not derived from natural WT1 protein, but \\ was modified from peptide-a. See text for details. \\ Both HLA-A ${ }^{\star 0201}$ and HLA-A*2402 are frequent HLA class I \\ types in human population.
}

(Table 2) because the CTL-induction system for the identification of CTL epitopes, such as stimulator cells, target cells, and peripheral blood mononuclear cell (PBMC) donors who have individual T-cell repertoires, is different depending on the report. For example, one group demonstrated that Db126induced CTLs showed stronger cytotoxic activity against WT1-expressing leukemia cells than WH187induced CTLs, while another group demonstrated that WH187-induced CTLs showed stronger cytotoxic activity against WT1-expressing colon cancer cells than Db126-induced CTLs[32,43]. One of the reasons that makes identification of CTL epitopes and prediction of immunologic activity of the candidate peptides difficult may be that the binding affinity of the peptides to MHC molecules does not necessarily correlate with the immunologic ability of the peptides because the high binding affinity of peptides to MHC molecules can induce tolerance in vivo, and the peptide/MHC complex-reactive T cells are prone to be eliminated or inactivated[34,44,45], and the remaining T-cell repertoires that can recognize the peptide/ MHC complex vary among individual patients.

\title{
Enhancement of Induction and Killing Activity of Human WT1-Specific CTLs using a Modified WT1 Peptide
}

We introduced a single amino-acid substitution, $\mathrm{M} \rightarrow \mathrm{Y}$, into the first anchor residue at position 2 of the natural immunogenic HLA-A*2402-restricted WT1 peptide, WT235[46] (Table 2). This substitution markedly increased the binding affinity of the peptide to the HLA-A*2402 molecule[46]. As expected from the increased binding affinity of the peptide, the modified WT235 peptide (CYTWNQMNL) elicited WT1-specific CTLs more efficiently than the natural peptide, WT235[46]. It was considered that the modified peptide-pulsed antigen-presenting cells strongly activated CTL precursors that could recognize the modified peptide/HLA-A*2402 complex, and that the CTLs induced by the stimulation with the modified WT235 killed not only the modified WT235 peptide-pulsed target cells, but also natural WT235 peptide-pulsed target cells, and, more importantly, endogenously WT1-expressing tumor cells with HLAA*2402 restriction and at higher efficiency than natural WT235-induced CTLs[46]. Thus, this modified WT1 peptide was expected to be very useful for a cancer vaccine targeting WT1 for HLA-A*2402positive patients. 


\section{No Inhibition of Normal Hematopoietic Cell Colony Formation by Human WT1- Specific CTLs}

Since several kinds of normal cells, including hematopoietic progenitor cells, physiologically express WT1, it is critical to know whether WT1 peptide-specific CTLs cause damage to normal cells physiologically expressing WT1 if we intend to apply the WT1-specific CTL-based immunotherapy in the clinical setting[33,34,35]. It was demonstrated that HLA-A*0201- or HLA-A*2402-restricted, WT1specific CTLs, which killed WT1-expressing tumor cells, did not inhibit colony formation by normal bone marrow cells[36,37,47], indicating that the CTLs did not attack WT1-expressing normal hematopoietic progenitor cells[34,35,36,37]. The selective CTL killing of leukemic blasts, but not normal hematopoietic progenitor cells, both of which express WT1, may be explained by the difference in the WT1 expression level between malignant and normal hematopoietic cells[36]. Other possible explanations may be differences in the mechanism of processing of WT1 protein and/or surface presentation of WT1 peptide, or differences in the susceptibility of the cell membranes to CTL-producing molecules, such as perforin, between malignant and normal cells. Further studies are needed to address this issue.

\section{Evidence of In Vivo Tumoricidal Activity of Human WT1-Specific CTLs using Immunodeficient Mouse Model}

In order to see whether human WT1-specific CTLs have tumoricidal activity in vivo, the WT1-specific CTLs and the restricting HLA allele-matched WT1-expressing leukemia cells[47,48] or solid cancer cells[49] were transplanted in immunodeficient mice. In these experiments, inhibition of the cancer cell growth due to attack by the CTLs was observed[47,48,49]. It was also shown that the CTLs did not inhibit engraftment of normal $\mathrm{CD} 34^{+}$hematopoietic stem cells[48]. These results strongly suggested that human WT1-specific CTLs had the ability to attack cancer cells, but not normal cells, in in vivo as well as in vitro settings.

\section{SPONTANEOUS IMMUNE RESPONSES AGAINST WT1 PROTEIN IN CANCER PATIENTS}

Several investigations, including ours, demonstrated that immune responses against the WT1 protein were naturally elicited in patients with hematopoietic malignancies, indicating that the WT1 protein had high immunogenicity in those patients[50,51,52,53,54,55,56]. These findings provided us with a rationale for developing cancer immunotherapy that targets WT1.

\section{Humoral Immune Responses against WT1 Protein in Patients with Hematopoetic Malignancies}

We demonstrated that more than half of the patients with hematopoetic malignancies, such as acute myeloid leukemia (AML), chronic myelogenous leukemia (CML), and myelodysplastic syndromes (MDS), responded in vivo to leukemia cell-derived WT1 protein and produced both IgM- and IgG-type WT1 antibody[52], indicating that not only WT1-specific B cells, but also T cells that were needed to induce class switch of WT1 antibody from $\operatorname{IgM}$ to $\operatorname{IgG}$, were activated in the patients. These results were basically compatible with those of other groups[50,51]. Intensive analysis of MDS patients revealed that class switch of WT1 antibody from IgM to IgG occurred along with the disease progression from refractory anemia (RA) to refractory anemia with excess of blast (RAEB), and further to RAEB in transformation (RAEB-t)[52], namely, with an increase in tumor burden. The stronger stimulation of the immune system by the higher tumor burden (more amount of WT1 protein) in patients with advanced 
stages of MDS might more strongly activate WT1-specific T cells to induce the class switch of the WT1 antibody. Furthermore, in AML patients, the WT1 antibody disappeared after the achievement of complete remission (CR), suggesting that the reduced stimulation of the immune system by the lesser amount of WT1 protein with decreased tumor burden in CR gave rise to discontinuation of WT1 antibody production[52]. These findings indicated that the WT1 protein was highly immunogenic and could elicit not only humoral, but also cellular, immune responses in the patients[50,51,52].

We also demonstrated more recently that Th1-type WT1 antibodies, such as $\operatorname{IgG} 1, \operatorname{IgG} 2$, and $\operatorname{IgG} 3$, were significantly increased in patients with leukemia and MDS compared to those in healthy volunteers, whereas Th2-type WT1 antibody, such as IgG4, did not increase in these patients[53]. These results showed that Th1-biased WT1-specific immune responses, which were essentially needed for cancer immunotherapy targeting WT1, might be elicited in patients with hematopoietic malignancies.

\section{$\mathrm{CD8}^{+} \mathrm{T}$ Cell Responses against WT1 Protein in Patients with Malignancies}

The question of whether leukemia-related, antigen-specific, $\mathrm{CD}^{+} \mathrm{T}$-cell responses spontaneously occurred in AML or CML patients with HLA-A*0201 was investigated[54,55]. T cells recognizing HLAA*0201/WT1 peptide complex could be detected at a relatively high rate by ELISPOT assay or intracellular IFN- $\gamma$ detection assay in PBMCs of AML patients[54]. This result provided direct evidence for spontaneous cellular T-cell responses against WT1 protein in patients with hematopoietic malignancies, such as AML. It is interesting that the responses to leukemia-related antigens, including WT1, were higher in CML patients after hematopoietic stem cell transplantation (HSCT) than in those before HSCT[55]. The increased responses to TAAs such as WT1 in CML patients after HSCT may be one of the possible explanations for the GVL effect of allogeneic HSCT. Using quantitative reverse transcription-PCR to measure IFN- $\gamma$ mRNA production by $\mathrm{CD} 8^{+} \mathrm{T}$ cells, Rezvani et al. also detected Tcell responses directed against HLA-A*0201-restricted WT1 epitopes in leukemia patients and healthy donors[56].

As for solid tumors, functional HLA-A*0201/WT1 tetramer-binding T cells could be expanded from tumor-draining lymph nodes, but not from peripheral blood, in patients with early-stage breast cancer[57]. This result strongly suggested that WT1 protein-responding CTLs were enriched or activated in the tumor-draining lymph nodes.

These data are results for HLA-A*0201-positive patients. We showed that HLA-A*2402/WT1 tetramer-binding $\mathrm{CD}^{+} \mathrm{T}$ cells were detected in peripheral blood of HLA-A*2402-positive patients with leukemia or solid tumors at higher frequencies than that of healthy donors[58].

Taken together from accumulated experimental data described above, we could speculate a scenario of spontaneous elicitation of WT1-specific immune responses in humans, as summarized in Fig. 1.

\section{MOUSE IN VIVO MODELS FOR WT1 CANCER VACCINE}

As mentioned above, several groups, including ours, succeeded in the generation of human WT1-specific CTLs from PBMCs in vitro. It is also very important to determine whether the WT1 protein could serve as a tumor rejection antigen in vivo. To address this issue, mouse models are essential because we can evaluate both the efficacy and the side effects of WT1 vaccination in vivo using these models.

\section{Tumor Rejection with No Autoaggression by WT1 Peptide or WT1 cDNA Vaccination in Prophylactic Mouse Models}

When we immunized C57BL/6 mice with activated, antigen-presenting cells (APCs) pulsed with Db126 peptide (a. a. 126-134, RMFPNAPYL: underlined letters represent anchor motifs for H-2D ${ }^{b}$ ), which had 


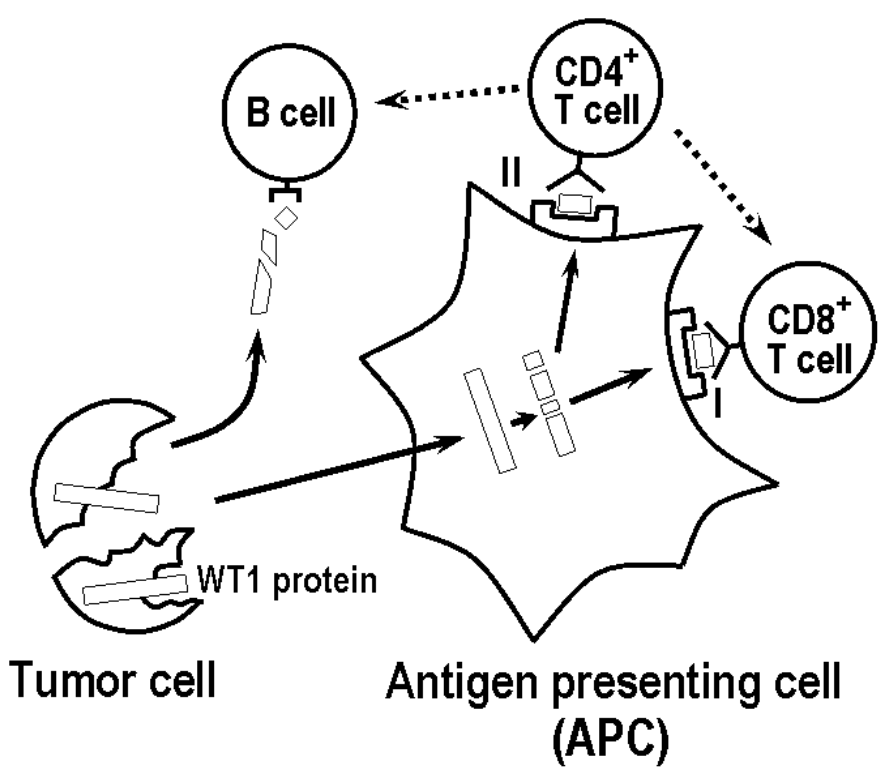

FIGURE 1. Spontaneous elicitation of immune responses against the WT1 protein. Tumor cell-derived WT1 protein stimulates B lymphocytes to produce anti-WT1 antibody, while the WT1 protein is ingested by APCs, such as dendritic cells (DCs), and is processed in them, followed by presentation of the WT1 protein-derived peptides in association with HLA molecules on the surface of the APCs. WT1 peptide/HLA class I complexes stimulate CD8 $8^{+} \mathrm{T}$ cells to make WT1-specific CTLs. WT1 peptide/HLA class II complexes stimulate $\mathrm{CD}^{+} \mathrm{T}$ cells to make WT1-specific, helper T cells, which more activate CTLs and B cells, respectively. The B cells "helped" by the helper T cells produce class-switched IgG-type, as well as IgM-type, anti-WT1 antibody.

relatively high binding affinity for $\mathrm{H}-2 \mathrm{D}^{\mathrm{b}}$ molecules and is by chance identical to the peptide used for the induction of human HLA-A*0201-restricted WT1-specific CTLs, the WT1 peptide-specific CTLs were shown to be generated from the spleen cells of the immunized mice[33]. The induced CTLs lysed WT1expressing tumor cells as well as the WT1 peptide-pulsed target cells. Furthermore, the immunized mice rejected challenges of WT1-expressing tumor cells more efficiently than nonimmunized mice[33]. To evaluate the risk of autoaggression by the immunization against normal WT1-expressing cells, namely, the side effects of WT1 peptide vaccination, the WT1-expressing normal tissues, such as pleura and kidney of the immunized mice, were examined histologically. The tissues showed normal structure and cellularity in all of the mice examined and no pathological changes caused by the immune response, such as lymphocyte infiltration or tissue destruction and repair, were observed, indicating that the CTLs against WT1 did not give damage to normal cells that physiologically expressed WT1[33].

We also developed a WT1 DNA vaccination system[59]. When plasmid DNA encoding mouse fulllength WT1 protein was injected intramuscularly into C57BL/6 mice, the vaccinated mice elicited CTLs against the WT1-expressing tumor cells[59]. Furthermore, the vaccinated mice rejected the challenges of WT1-expressing tumor cells and about $50 \%$ of the vaccinated mice survived, while none of the mice injected with control plasmid DNA survived[59]. WT1 DNA vaccination, as well as WT1 peptide vaccination, gave no pathological damage to physiologically WT1-expressing tissues, such as kidney[59]. In addition, no difference in the colony numbers of CFU-GEMM, CFU-GM, CFU-G, or BFU-E was observed between the immunized and nonimmunized mice, indicating that bone marrow hematopoetic progenitor cells that physiologically expressed WT1 were not damaged by the CTLs induced by the WT1 DNA vaccination[59]. These findings indicated that the WT1 DNA-vaccinated mice could reject WT1expressing tumor cells with no signs of autoaggression caused by the induced WT1-specific CTLs. 


\section{Tumor Rejection with No Autoaggression by WT1 Peptide Vaccination in a Therapeutic Mouse Model}

In order to examine whether WT1 peptide vaccination had the potency to reject tumor cells in therapeutic settings, we developed the following novel system. Intradermal injection of Mycobacterium bovis bacillus Calmette-Guerin cell wall skeleton (BCG-CWS) as an adjuvant into C57BL/6 mice, followed by intradermal injection of WT1 peptide (Db126 peptide) at the same site on the next day, generated WT1specific CTLs and led to the rejection of WT1-expressing leukemia or lung cancer cells that had been implanted into the mice prior to the vaccinations[60]. The mice vaccinated with the WT1 peptide in combination with BCG-CWS survived significantly longer than the control mice, namely, mice with no treatment, mice vaccinated with the WT1 peptide alone, or mice injected with BCG-CWS alone[60]. No damage in physiologically WT1-expressing normal tissues, such as kidney and bone marrow, in the mice vaccinated with the peptide and BCG-CWS was observed. BCG-CWS was shown to be effective for eliciting TAA (WT1 in this case)-specific immunity to reject tumor challenges when it was injected in combination with TAA-derived peptides[60]. Because BCG-CWS is now being used in human settings[61,62,63], it may be used as a strong adjuvant in combination with WT1 peptide vaccine for cancer immunotherapy in the near future.

\section{CLINICAL TRIALS OF WT1 PEPTIDE CANCER VACCINE}

At a "laboratory experiment" level, as described so far in this article, we and others obtained results that demonstrated that WT1 was one of the most suitable (strong and safe) tumor antigen candidates for cancer immunotherapy. On the basis of these results, we performed a phase I clinical trial of cancer immunotherapy targeting the WT1 protein, namely, a trial of the WT1 peptide cancer vaccine for HLAA*2402-positive patients with leukemia, MDS, lung cancer, or breast cancer[58,64,65]. We used HLAA*2402-restricted WT1 peptide with Montanide ISA51 as adjuvant because it is one of the most commonly and safely used adjuvants[66,67], and is therefore considered to be appropriate for phase I clinical trials in which we mainly evaluate the toxicity of the peptide vaccine. We injected $0.3,1.0$, or 3.0 mg of WT1 peptide intradermally per body at 2-week intervals. We observed clinical responses in some cases after the vaccination, as reported recently[58,64,65].

A patient with overt leukemia from MDS, who had HLA-A*2402, was injected intradermally with $0.3 \mathrm{mg}$ of an HLA-A*2402-restricted, 9-mer WT1 peptide emulsified with Montanide ISA51 adjuvant[64] (Fig. 2). The vaccination resulted in an increase in WT1-specific CTLs in peripheral blood[64], followed by a rapid reduction in leukemic blast cells and WT1 levels in the bone marrow. Severe leukocytopenia was also observed. It was speculated that the leukocytopenia was induced because most normal-appearing peripheral blood cells in MDS patients were derived from WT1-expressing transformed hematopoietic stem/progenitor cells[64,68], which were attacked by the vaccination-induced CTLs. It is likely that leukocytopenia was specific to MDS patients in which hematopoiesis was mainly sustained by transformed hematopoietic cells. Therefore, the leukocytopenia was considered to be a clinical effect as well as an adverse effect[58,64]. Another MDS patient vaccinated with the WT1 peptide and Montanide ISA51 adjuvant also had a similar clinical course[64]. These two patients are the first reported cases in which WT1 peptide vaccination was performed and showed clinical responses of reducing leukemic blast cells, i.e., tumor burden. In some de novo AML patients who were in hematological complete remission, but had minimal residual disease at microscopic and/or molecular levels, a decrease in residual leukemic cells and/or WT1 expression level which reflected minimal residual deseases was observed (Fig. 3). In contrast to MDS patients, leukocytopenia was not observed because normal hematopoiesis remained enough in the de novo AML patients[58]. 


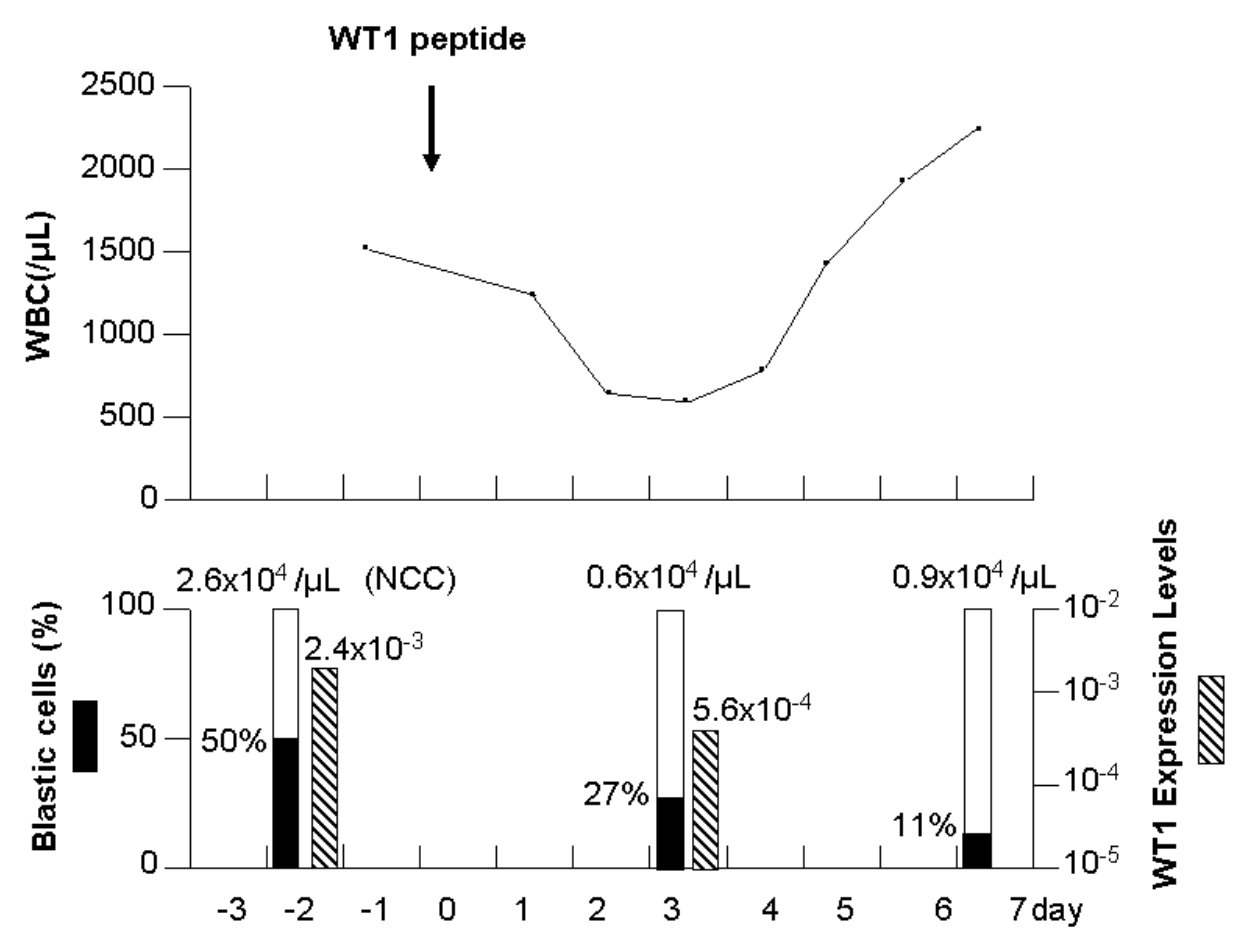

FIGURE 2. Reduction of blast cells and WT1 expression level in bone marrow, concomitant with leukocytopenia, in an MDS-derived AML patient treated with the WT1 peptide vaccination. Speculation for mechanism of the simultaneous occurrence of leukemic blast cell reduction and leukocytopenia is described in the text. WBC count was recovered by administration of G-CSF and steroid to stop the vaccinationmediated immune reaction. NCC: nucleated cell count. This figure was modified from that in Oka, Y. et al. (2003) Int. J. Hematol. 78, 56-61.

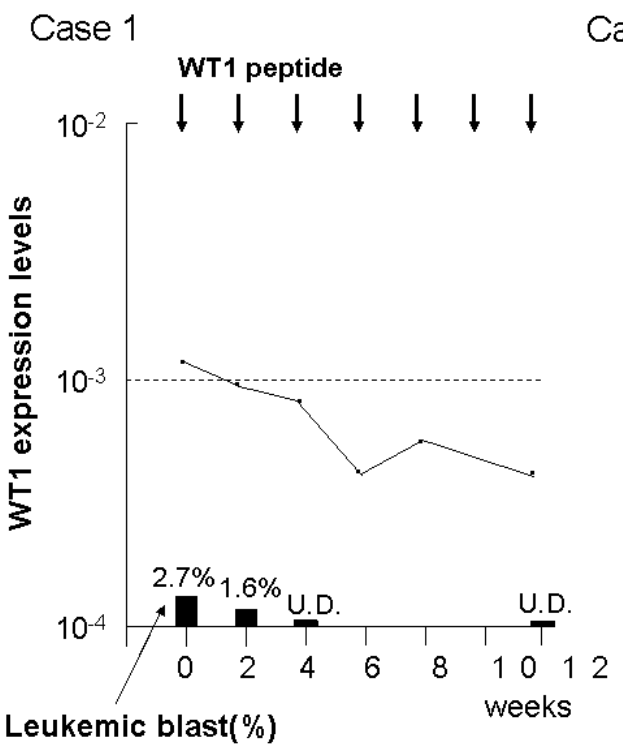

Case 2

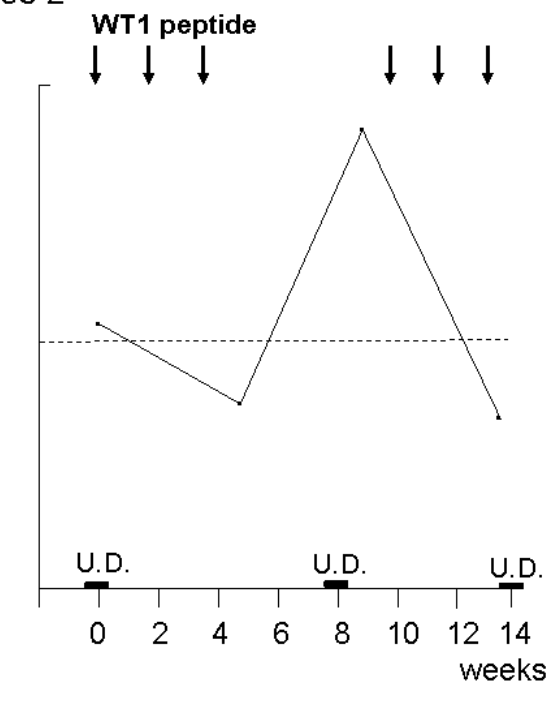

FIGURE 3. Reduction of leukemic blast cells and/or WT1 expression levels in bone marrow without leukocytopenia in de novo AML patients treated with WT1 peptide vaccination. In case 2, decrease of WT1 expression level was observed with the WT1 peptide vaccination, followed by increase of the WT1 level after cessation of the vaccination. The WT1 level decreased again after the restart of the vaccine. Correlation between the WT1 peptide vaccination and the WT1 level reduction was strongly suggested. U.D.: undetectable. This figure was modified from that in in Oka, Y. et al. (2004) Proc. Natl. Acad. Sci. U.S.A. 101, 13885-13890. 
In this phase I clinical trial, of the 14 patients with leukemia, including de novo leukemia and MDS, seven patients showed clinical responses, such as a reduction of leukemic cells and/or WT1 expression level[58].

Independently of our group, another group also reported an AML patient with HLA-A*0201 in whom complete remission was achieved and maintained by the vaccination with HLA-A*0201-restricted WT1 peptide (Db126)[32,69]. They vaccinated the patient with the WT1 peptide with GM-CSF and KLH[69]. No toxicity against the function of WT1-expressing normal tissues, including bone marrow and kidney, was observed[69].

In addition to leukemia patients, we observed clinical responses to the WT1 vaccination in solid cancer patients. A patient (HLA-A*2402) with lung cancer, that was completely resistant to chemotherapy and progressive, was injected with $0.3 \mathrm{mg}$ of HLA-A*2402-restricted WT1 peptide[65]. Chorioembryonic antigen (CEA), a tumor marker, significantly decreased and the largest mass among the multiple tumors in the lung fields was slightly reduced after the vaccination[65]. Another patient (HLA$A * 2402$ ) with lung cancer, in whom operative resection of tumor masses in lung was performed, was injected with $0.3 \mathrm{mg}$ of HLA-A*2402-restricted WT1 peptide after the reincrease of sialyl Lewis (x) (SLX), a tumor marker, which indicated regrowth of the tumor after the operation. SLX began to decrease after the first vaccination and returned to a normal level[65]. In this patient, WT1 vaccination has been repeated with maintained clinical benefit for more than 1 year without significant adverse effects, indicating that the induced WT1-specific CTLs did not give damage to physiologically WT1-expressing normal tissues, including normal hematopoietic stem/progenitor cells and kidney podocytes.

In two of the breast cancer patients enrolled in this study, metastatic tumors regressed after the WT1 vaccination[58]. One example is shown in Fig. 4, in which metastatic tumors in the lung regressed. In another patient, the WT1 vaccination has been repeated for more than 1.5 years because the clinical benefit persisted during the time. The patient could not eat food because of ileus caused by the metastatic tumors in the colon before the WT1 vaccination. After the vaccination, the tumor regressed[58], accompanied by improvement of appetite and relief from meteorism. The patient could spend her daily life without limitation of daily activities, including oral ingestion, during most of the vaccination period.

$\mathbf{a}$

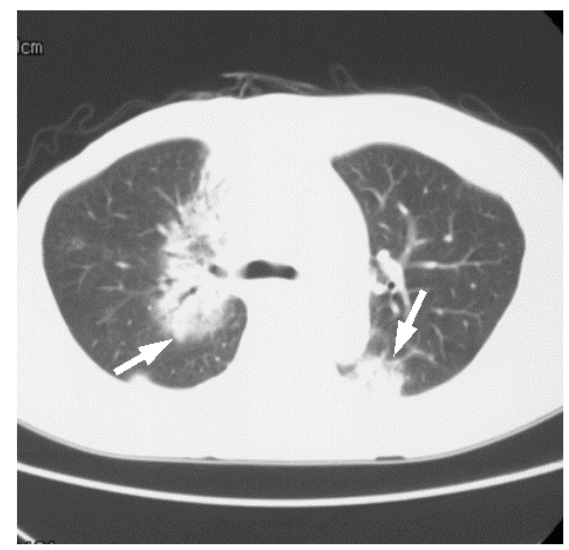

Before vaccination b

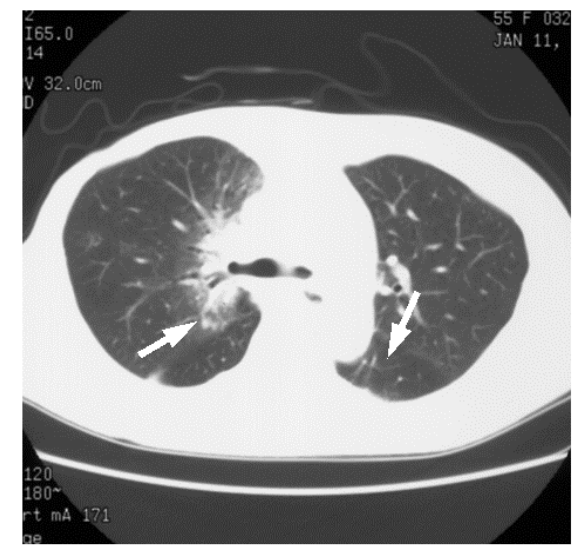

After vaccination

FIGURE 4. A representative case with solid cancer that showed clinical response to the WT1 peptide vaccination. This case is a breast cancer patient with lung metastasis. The metastatic tumors (indicated with arrows) detected before the vaccination (a) regressed after the vaccination (b). This figure was modified from that in Oka, Y. et al. (2004) Proc. Natl. Acad. Sci. U.S.A. 101, 1388513890. Copyright National Academy of Sciences, USA. 
Taken together for solid cancer patients, of the 12 patients with lung or breast cancer in the phase I clinical trial, five patients showed clinical responses, such as decrease in tumor size or tumor marker[58]. Treatment of more patients with more various kinds of solid cancer is needed to evaluate precisely the clinical efficacy of the WT1 vaccination for solid cancer patients. How to evaluate clinical responses in immunotherapy, whose action mechanism is completely different from that of chemotherapy, is also an important issue. We would like to discuss this issue later in "Future Directions".

In the phase I clinical study, a significant correlation between immunological (increase in WT1/HLAtetramer-positive CTLs) and clinical response was observed in the 19 evaluable patients, indicating that WT1-specific CTLs induced by WT1 vaccination played an important role in the clinical response[58].

No damage to physiologically WT1-expressing normal tissues was observed in the patients who had clinical responses after the vaccination, as it was expected from preclinical data[33,36,37,47,59,60]. Therefore, it was considered that the induced CTLs attacked WT1-expressing tumor cells, but not physiologically WT1-expressing normal cells. Possible mechanisms to explain this observation were mentioned before in "No Inhibition of Normal Hematopoietic Cell Colony Formation by Human WT1Specific CTLs". Furthermore, inflammation existing in tumor sites, but not in normal tissues, might contribute to the migration of the WT1-specific CTLs to tumor cells and to the activation of the CTLs, which could then become strong enough to kill tumor cells.

We are now conducting a phase I/II trial of weekly injection of WT1 peptide vaccine for patients with various kinds of solid cancers in addition to lung or breast cancers that were included in the former phase I clinical trial. The phase I part composed of the first 10 patients has been finished[70]. The vaccinationrelated systemic toxicities were not observed. Of the 10 patients, one patient (glioblastoma) exhibited a partial response (PR) and five additional patients had stable disease (SD) during the treatment period of 12 weeks.

\section{NEW TARGET DISEASES FOR WT1-DIRECTED CANCER IMMUNOTHERAPY}

Recently, two kinds of hematological malignancies, non-Hodgkin lymphoma (NHL) and multiple myeloma, were presented as candidates for target diseases for WT1-directed immunotherapy.

Although WT1 expression in NHL cells has not been studied, Drakos et al. assessed for WT1 expression in 167 NHLs using immunohistochemical methods[71]. WT1 protein was frequently detected, primarily in the cytoplasm, of a subset of high-grade NHLs[71] (Table 1).

The expression levels of WT1 mRNA in myeloma cells were significantly lower than those in acute leukemia cells, leading to a tentative conclusion that multiple myeloma was not a good target disease for WT1-directed cancer immunotherapy. However, a recent investigation showed that myeloma cells were lysed efficiently by WT1-specific CTLs in an HLA-restricted manner in spite of the low expression level of WT1 mRNA in the cells[72]. The authors demonstrated that the high sensitivity of the myeloma cells to CTL-mediated cytotoxicity appeared to be because of the high susceptibility of the cell membranes to perforin.

Thus, WT1-directed cancer immunotherapy targeting NHL and multiple myeloma should also be planned (Table 1).

\section{FUTURE DIRECTIONS}

Based on data accumulated from basic (preclinical) research, we and others have started clinical trials of WT1 peptide cancer vaccine as translational research. Fortunately, it was revealed that the WT1 vaccine had clinical efficacy at least for some patients with malignant neoplasms. Our goal is to establish a WT1 protein-targeted cancer vaccine that is strong enough to eradicate residual cancer cells and can be applied to patients with various kinds of malignant neoplasms by enhancing the power of the WT1 cancer vaccine. Strategies to enhance immunologically the power of TAA-derived peptide cancer vaccines may 
include (1) finding or developing more strong adjuvants, (2) using HLA class II-restricted helper epitopes that can enhance the induction and activation of CTLs and make "memory" CTLs in combination with HLA class I-restricted CTL epitopes[73,74,75,76], and (3) using multiple epitope peptides[77,78]. Efforts for the enhancement of cancer vaccine power using these strategies are under way.

Combined usage of cancer vaccines and other kinds of drugs, including molecular-target-based drugs such as imatinib[78], or chemotherapy drugs[79,80,81], might be another strategy to develop a novel modality for anticancer action. It was recently reported that addition of a multipeptide vaccine against BCR-ABL-derived p210 fusion protein to conventional treatment (imatinib) in patients with CML induced improved cytogenetic responses[78]. Blockade or removal of regulatory $\mathrm{T}$ cells by using approaches such as administration of cyclophosphamide or gemcitabine-containing chemotherapy might improve the efficacy of peptide vaccines[79,80,81]. Gemcitabine was also revealed in a mouse model to eliminate splenic $\mathrm{Gr}-1^{+} / \mathrm{CD} 11 \mathrm{~b}^{+}$myeloid suppressor cells that contributed to immunosuppression by inhibiting the function of $\mathrm{CD}^{+} \mathrm{T}$ cells[81].

In contrast to the vaccination for patients with solid cancer or de novo acute leukemia, it may be better to reduce the peptide dosage for treatment of patients with MDS or CML so that malignant cells are damaged gradually, not rapidly, because hematopoiesis in these patients is mainly sustained by malignant hematopoietic stem or progenitor cell-derived mature cells, and therefore, rapid and strong destruction of these malignant cell-sustained hematopoiesis before recovery of normal hematopoiesis may induce pancytopenia in peripheral blood, as described before in this article (Fig. 2). In fact, vaccination of a chronic myelomonocytic leukemia (CMML) patient, a hematological stem cell desease, with a very low dose of the WT1 peptide could reduce abnormal immature hematopoietic cells without leukocytopenia[82].

Possible strategies to improve the WT1 peptide vaccine from immunological aspect are summarized in Table 3.

\section{TABLE 3}

Immunological Aspect-Based Strategies to Improve WT1 Peptide Vaccine

\begin{tabular}{ll}
\hline Strategies & \multicolumn{1}{c}{ Expected Effects } \\
\hline $\begin{array}{l}\text { Use of stronger adjuvant } \\
\text { Combined use with WT1-derived helper peptide }\end{array}$ & $\begin{array}{l}\text { More activation of DCs at vaccine injection sites } \\
\text { Activation of WT1-specific CD4 }{ }^{+} \text {T cells to further activate } \\
\text { WT1-specific CTLs and make "memory" CTLs }\end{array}$ \\
$\begin{array}{l}\text { Use of multiple epitope peptides } \\
\text { Combined use with chemotherapy }\end{array}$ & $\begin{array}{l}\text { Activation of different kinds of CTLs } \\
\text { Reduction of WT1 peptide dosage for MDS or CML }\end{array}$ \\
& $\begin{array}{l}\text { Gradual decrease of malignant cells to make enough time } \\
\text { for recovery of normal hematopoiesis (hematopoiesis is } \\
\text { mainly sustained by malignant cells in patients with the } \\
\text { diseases. }\end{array}$ \\
\hline
\end{tabular}

* See text for the details.

DC: dendritic cell, CTL: cytotoxic T lymphocyte, Treg: regulatory T-cell, MDS: myelodysplastic syndromes, CML: chronic myelogenous leukemia.

Translational research is composed of basic research and the subsequent clinical trials. The latter is based on the scientific data obtained from the former. In other words, the data obtained in the clinical trials have a scientific basis. Therefore, it is expected that we will be able to obtain valuable scientific information about immune responses against TAAs in tumor-bearing patients by analyzing the samples (blood, bone marrow, tumor, or vaccinated site) obtained from the patients treated with the WT1 peptide 
cancer vaccine. This information will be useful not only for understanding the immune responses against TAAs in tumor-bearing patients, but also for further improvement of the cancer vaccine.

Chemotherapy drugs directly attack cancer cells, while cancer vaccines do not. The latter activate the immune system to attack cancer cells. Therefore, we may need new "response evaluation criteria" specific for cancer vaccine therapy[83]. It is probable that some cancer patients treated with cancer vaccines will be able to survive long term without complete disappearance of the tumors and with good quality of life (QOL)[58,65], or that the tumor growth will be stabilized or even regress after a temporary increase in size because immunotherapy is generally not as quick acting as chemotherapy $[83,84]$. Therefore, when we evaluate the vaccination-induced clinical responses with the Response Evaluation Criteria in Solid Tumors (RECIST) system, which is a gold standard for evaluating the response of solid tumors in the field of cancer chemotherapy, it might be recommended that stable disease (SD) is more highly regarded in cancer immunotherapy than cancer chemotherapy, particularly when the SD periods persist for a long while, and that stabilization of the disease after temporary progression of disease, which is categorized as progressive disease (PD) in RECIST, is also evaluated favorably, like "stabilization after temporal PD", based on the maximal size at the time point of the cessation of tumor growth. Although we should not excessively expect efficacy of cancer vaccine, we should not underestimate the efficacy.

Once we accumulate evidences that show the ability of the WT1 peptide vaccine to suppress tumor growth in patients with rather high tumor burden, we should start clinical trials in "adjuvant settings" in which diseases are minimal after operation and/or chemotherapy. Adjuvant settings would be the most suitable settings for cancer vaccines to show their ability. Recurrence of the diseases might be significantly reduced by the vaccination.

\section{ACKNOWLEDGMENTS}

This study was supported in part by a Grant-in-Aid from the Ministry of Education, Science, Sports and Culture and the Ministry of Health, Labor, and Welfare, Japan. We thank Ms. T. Umeda and Ms. Y. Watatani for their help in enrollment of patients for clinical trials and arrangement of the patients' samples and data. We also thank Ms. K. Hamada for preparation of this manuscript.

\section{REFERENCES}

1. Call, K.M., Glaser, T., Ito, C.Y., Buckler, A.J., Pelletier, J., Haber, D.A., Rose, E.A., Kral, A., Yeger, H., Lewis, W.H., Jones, C., and Housman D.E. (1990) Isolation and characterization of a zinc finger polypeptide gene at the human chromosome 11 Wilms' tumor locus. Cell 60, 509-520.

2. Gessler, M., Poustka, A., Cavenee, W., Neve, R.L., Orkin, S.H., and Bruns, G.A. (1990) Homozygous deletion in Wilms tumours of a zinc-finger gene identified by chromosome jumping. Nature 343, 774-778.

3. Drummond, I.A., Madden, S.L., Rohwer-Nutter, P., Bell, G.I., Sukhatme, V.P., and Rauscher, F.J., 3rd (1992) Repression of the insulin-like growth factor II gene by the Wilms tumor suppressor WT1. Science 257, 674-678.

4. $\quad$ Englert, C., Hou, X., Maheswaran, S., Bennett, P., Ngwu, C., Re, G.G., Garvin, A.J., Rosner, M.R., and Haber, D.A. (1995) WT1 suppresses synthesis of the epidermal growth factor receptor and induces apoptosis. EMBO J. 14, 46624675 .

5. Goodyer, P., Dehbi, M., Torban, E., Bruening, W., and Pelletier, J. (1995) Repression of the retinoic acid receptoralpha gene by the Wilms' tumor suppressor gene product, wt1. Oncogene 10, 1125-1129.

6. Hewitt, S.M., Hamada, S., McDonnell, T.J., Rauscher, F.J., 3rd, and Saunders, G.F. (1995) Regulation of the protooncogenes bcl-2 and c-myc by the Wilms' tumor suppressor gene WT1. Cancer Res. 55, 5386-5389.

7. Kim, J., Prawitt, D., Bardeesy, N., Torban, E., Vicaner, C., Goodyer, P., Zabel, B., and Pelletier, J. (1999) The Wilms' tumor suppressor gene (wt1) product regulates Dax-1 gene expression during gonadal differentiation. Mol. Cell. Biol. 19, 2289-2299.

8. Miwa, H., Beran, M., and Saunders, G.F. (1992) Expression of the Wilms' tumor gene (WT1) in human leukemias. Leukemia 6, 405-409.

9. $\quad$ Miyagi, T., Ahuja, H., Kubota, T., Kubonishi, I., Koeffler, H.P., and Miyoshi, I. (1993) Expression of the candidate Wilm's tumor gene, WT1, in human leukemia cells. Leukemia 7, 970-977.

10. Inoue, K., Sugiyama, H., Ogawa, H., Nakagawa, M., Yamagami, T., Miwa, H., Kita, K., Hiraoka, A., Masaoka, T., 
Nasu, K., Kyo, T., Dohy, H., Nakauchi, H., Ishidate, T., Akiyama, T., and Kishimoto, T. (1994) WT1 as a new prognostic factor and a new marker for the detection of minimal residual disease in acute leukemia. Blood 84, 30713079 .

11. Brieger, J., Weidmann, E., Fenchel, K., Mitrou, P.S., Hoelzer, D., and Bergmann, L. (1994) The expression of the Wilms' tumor gene in acute myelocytic leukemias as a possible marker for leukemic blast cells. Leukemia 8, 21382143.

12. Menssen, H.D., Renkl, H.J., Rodeck, U., Maurer, J., Notter, M., Schwartz, S., Reinhardt, R., and Thiel, E. (1995) Presence of Wilms' tumor gene (wt1) transcripts and the WT1 nuclear protein in the majority of human acute leukemias. Leukemia 9, 1060-1067.

13. Bergmann, L., Miething, C., Maurer, U., Brieger, J., Karakas, T., Weidmann, E., and Hoelzer, D. (1997) High levels of Wilms' tumor gene (wt1) mRNA in acute myeloid leukemias are associated with a worse long-term outcome. Blood 90, 1217-1225.

14. Menssen, H.D., Renkl, H.J., Rodeck, U., Kari, C., Schwartz, S., and Thiel, E. (1997) Detection by monoclonal antibodies of the Wilms' tumor (WT1) nuclear protein in patients with acute leukemia. Int. J. Cancer 70, 518-523.

15. Tamaki, H., Ogawa, H., Ohyashiki, K., Ohyashiki, J.H., Iwama, H., Inoue, K., Soma, T., Oka, Y., Tatekawa, T., Oji, Y., Tsuboi, A., Kim, E.H., Kawakami, M., Fuchigami, K., Tomonaga, M., Toyama, K., Aozasa, K., Kishimoto, T., and Sugiyama, H. (1999) The Wilms' tumor gene WT1 is a good marker for diagnosis of disease progression of myelodysplastic syndromes. Leukemia 13, 393-399.

16. Ogawa, H., Tamaki, H., Ikegame, K., Soma, T., Kawakami, M., Tsuboi, A., Kim, E.H., Hosen, N., Murakami, M., Fujioka, T., Masuda, T., Taniguchi, Y., Nishida, S., Oji, Y., Oka, Y., and Sugiyama, H. (2003) The usefulness of monitoring WT1 gene transcripts for the prediction and management of relapse following allogeneic stem cell transplantation in acute type leukemia. Blood 101, 1698-1704.

17. Oji, Y., Ogawa, H., Tamaki, H., Oka, Y., Tsuboi, A., Kim, E.H., Soma, T., Tatekawa, T., Kawakami, M., Asada, M., Kishimoto, T., and Sugiyama, H. (1999) Expression of the Wilms' tumor gene WT1 in solid tumors and its involvement in tumor cell growth. Jpn. J. Cancer Res. 90, 194-204.

18. Oji, Y., Miyoshi, S., Maeda, H., Hayashi, S., Tamaki, H., Nakatsuka, S., Yao, M., Takahashi, E., Nakano, Y., Hirabayashi, H., Shintani, Y., Oka, Y., Tsuboi, A., Hosen, N., Asada, M., Fujioka, T., Murakami, M., Kanato, K., Motomura, M., Kim, E. H., Kawakami, M., Ikegame K., Ogawa, H., Aozasa, K., Kawase, I., and Sugiyama, H. (2002) Overexpression of the Wilms' tumor gene WT1 in de novo lung cancers. Int. J. Cancer 100, 297-303.

19. Miyoshi, Y., Ando, A., Egawa, C., Taguchi, T., Tamaki, Y., Tamaki, H., Sugiyama, H., and Noguchi, S. (2002) High expression of Wilms' tumor suppressor gene predicts poor prognosis in breast cancer patients. Clin. Cancer Res. 8, 1167-1171.

20. Oji, Y., Miyoshi, Y., Koga, S., Nakano, Y., Ando, A., Nakatsuka, S., Ikeba, A., Takahashi, E., Sakaguchi, N., Yokota, A., Hosen, N., Ikegame, K., Kawakami, M., Tsuboi, A., Oka, Y., Ogawa, H., Aozasa, K., Noguchi, S., and Sugiyama, H. (2003) Overexpression of the Wilms' tumor gene WT1 in primary thyroid cancer. Cancer Sci. 94, 606-611.

21. Oji, Y., Yamamoto, H., Nomura, M., Nakano, Y., Ikeba, A., Nakatsuka, S., Abeno, S., Kiyotoh, E., Jomgeow, T., Sekimoto, M., Nezu, R., Yoshikawa, Y., Inoue, Y., Hosen, N., Kawakami, M., Tsuboi, A., Oka, Y., Ogawa, H., Souda, S., Aozasa, K., Monden, M., and Sugiyama, H. (2003) Overexpression of the Wilms' tumor gene WT1 in colorectal adenocarcinoma. Cancer Sci. 94, 712-717.

22. Oji, Y., Suzuki, T., Nakano, Y., Maruno, M., Nakatsuka, S., Jomgeow, T., Abeno, S., Tatsumi, N., Yokota, A., Aoyagi, S., Nakazawa, T., Ito, K., Kanato, K., Shirakata, T., Nishida, S., Hosen, N., Kawakami, M., Tsuboi, A., Oka, Y., Aozasa, K., Yoshimine, T., and Sugiyama, H. (2004) Overexpression of the Wilms' tumor gene W T1 in primary astrocytic tumors. Cancer Sci. 95, 822-827.

23. Nakahara, Y., Okamoto, H., Mineta, T., and Tabuchi, K. (2004) Expression of the Wilms' tumor gene product WT1 in glioblastomas and medulloblastomas. Brain Tumor Pathol. 21, 113-116.

24. Oji, Y., Yano, M., Nakano, Y., Abeno, S., Nakatsuka, S., Ikeba, A., Yasuda, T., Fujiwara, Y., Takiguchi, S., Yamamoto, H., Fujita, S., Kanato, K., Ito, K., Jomgeow, T., Kawakami, M., Tsuboi, A., Shirakata, T., Nishida, S., Hosen, N., Oka, Y., Aozasa, K., Monden, M., and Sugiyama, H. (2004) Overexpression of the Wilms' tumor gene WT1 in esophageal cancer. Anticancer Res. 24, 3103-3108.

25. Oji, Y., Nakamori, S., Fujikawa, M., Nakatsuka, S., Yokota, A., Tatsumi, N., Abeno, S., Ikeba, A., Takashima, S., Tsujie, M., Yamamoto, H., Sakon, M., Nezu, R., Kawano, K., Nishida, S., Ikegame, K., Kawakami, M., Tsuboi, A., Oka, Y., Yoshikawa, K., Aozasa, K., Monden, M., and Sugiyama, H. (2004) Overexpression of the Wilms' tumor gene WT1 in pancreatic ductal adenocarcinoma. Cancer Sci. 95, 583-587.

26. Yamagami, T., Sugiyama, H., Inoue, K., Ogawa, H., Tatekawa, T., Hirata, M., Kudoh, T., Akiyama, T., Murakami, A., and Maekawa, T. (1996) Growth inhibition of human leukemic cells by WT1 (Wilms tumor gene) antisense oligodeoxynucleotides: implications for the involvement of WT1 in leukemogenesis. Blood 87, 2878-2884.

27. Inoue, K., Tamaki, H., Ogawa, H., Oka, Y., Soma, T., Tatekawa, T., Oji, Y., Tsuboi, A., Kim, E.H. ,Kawakami, M., Akiyama, T., Kishimoto, T., and Sugiyama, H. (1998) Wilms' tumor gene (WT1) competes with differentiationinducing signal in hematopoietic progenitor cells. Blood 91, 2969-2976

28. Tsuboi, A., Oka, Y., Ogawa, H., Elisseeva, O.A., Tamaki, H., Oji, Y., Kim, E.H., Soma, T., Tatekawa, T., Kawakami, M., Kishimoto, T., and Sugiyama, H. (1999) Constitutive expression of the Wilms' tumor gene WT1 inhibits the differentiation of myeloid progenitor cells but promotes their proliferation in response to granulocyte-colony 
stimulating factor (G-CSF). Leuk. Res. 23, 499-505.

29. Melief, C.J. and Kast, W.M. (1995) T-cell immunotherapy of tumors by adoptive transfer of cytotoxic T lymphocytes and by vaccination with minimal essential epitopes. Immunol. Rev. 145, 167-177.

30. Rosenberg, S.A. (2001) Progress in human tumour immunology and immunotherapy. Nature 411, 380-384.

31. Ritz, J. (1994) Tumor immunity: will new keys unlock the door? J. Clin. Oncol. 12, 237-238.

32. Oka, Y., Elisseeva, O.A., Tsuboi, A., Ogawa, H., Tamaki, H., Li, H., Oji, Y., Kim, E.H., Soma, T., Asada, M., Ueda, K., Maruya, E., Saji, H., Kishimoto, T., Udaka, K., and Sugiyama, H. (2000) Human cytotoxic T-lymphocyte responses specific for peptides of the wild-type Wilms' tumor gene (WT1 ) product. Immunogenetics 51, 99-107.

33. Oka, Y., Udaka, K., Tsuboi, A., Elisseeva, O.A., Ogawa, H., Aozasa, K., Kishimoto, T., and Sugiyama, H. (2000) Cancer immunotherapy targeting Wilms' tumor gene WT1 product. J. Immunol. 164, 1873-1880.

34. Oka, Y., Tsuboi, A., Elisseeva, O.A., Udaka, K., and Sugiyama, H. (2002) WT1 as a novel target antigen for cancer immunotherapy. Curr. Cancer Drug Targets 2, 45-54.

35. Sugiyama, H. (2002) Cancer immunotherapy targeting WT1 protein. Int. J. Hematol. 76, 127-132.

36. Gao, L., Bellantuono, I., Elsasser, A., Marley, S.B., Gordon, M.Y., Goldman, J.M., and Stauss, H.J. (2000) Selective elimination of leukemic CD34(+) progenitor cells by cytotoxic T lymphocytes specific for WT1. Blood 95, 21982203.

37. Ohminami, H., Yasukawa, M., and Fujita, S. (2000) HLA class I-restricted lysis of leukemia cells by a CD8(+) cytotoxic T-lymphocyte clone specific for WT1 peptide. Blood 95, 286-293.

38. Makita, M., Hiraki, A., Azuma, T., Tsuboi, A., Oka, Y., Sugiyama, H., Fujita, S., Tanimoto, M., Harada, M., and Yasukawa, M. (2002) Antilung cancer effect of WT1-specific cytotoxic T lymphocytes. Clin. Cancer Res. 8, 26262631.

39. Bellantuono, I., Gao, L., Parry, S., Marley, S., Dazzi, F., Apperley, J., Goldman, J.M., and Stauss, H.J. (2002) Two distinct HLA-A0201-presented epitopes of the Wilms tumor antigen 1 can function as targets for leukemia-reactive CTL. Blood 100, 3835-3837.

40. Li, Z., Oka, Y., Tsuboi, A., Masuda, T., Tatsumi, N., Kawakami, M., Fujioka, T., Sakaguchi, N., Nakajima, H., Fujiki, F., Udaka, K., Oji, Y., Kawase, I., and Sugiyama, H. (2005) WT1(235), a ninemer peptide derived from Wilms' tumor gene product, is a candidate peptide for the vaccination of HLA-A*0201-positive patients with hematopoietic malignancies. Int. J. Hematol. 82, 458-459.

41. Azuma, T., Makita, M., Ninomiya, K., Fujita, S., Harada, M., and Yasukawa, M. (2002) Identification of a novel WT1-derived peptide which induces human leucocyte antigen-A24-restricted anti-leukaemia cytotoxic T lymphocytes. Br. J. Haematol. 116, 601-603.

42. Savage, P., Gao, L., Vento, K., Cowburn, P., Man, S., Steven, N., Ogg, G., McMichael, A., Epenetos, A., Goulmy, E., and Stauss, H.J. (2004) Use of B cell-bound HLA-A2 class I monomers to generate high-avidity, allo-restricted CTLs against the leukemia-associated protein Wilms tumor antigen. Blood 103, 4613-4615.

43. Koesters, R., Linnebacher, M., Coy, J.F., Germann, A., Schwitalle, Y., Findeisen, P., and Von Knebel Doeberitz, M. (2004) WT1 is a tumor-associated antigen in colon cancer that can be recognized by in vitro stimulated cytotoxic T cells. Int. J. Cancer 109, 385-392.

44. Moudgil, K. and Sercarz, E. (1994) Can antitumor immune responses discriminate between self and nonself? Immunol. Today 15, 353-355.

45. Ohno, S. (1992) How cytotoxic T cells manage to discriminate nonself from self at the nonapeptide level. Proc. Natl. Acad. Sci. U. S. A. 89, 4643-4647.

46. Tsuboi, A., Oka, Y., Udaka, K., Murakami, M., Masuda, T., Nakano, A., Nakajima, H., Yasukawa, M., Hiraki, A., Oji, Y., Kawakami, M., Hosen, N., Fujioka, T., Wu, F., Taniguchi, Y., Nishida, S., Asada, M., Ogawa, H., Kawase, I., and Sugiyama, H. (2002) Enhanced induction of human WT1-specific cytotoxic T lymphocytes with a 9-mer WT1 peptide modified at HLA-A*2402-binding residues. Cancer Immunol. Immunother. 51, 614-620. Doubrovina, E.S., Doubrovin, M.M., Lee, S., Shieh, J.H., Heller, G., Pamer, E., and O'Reilly, R.J. (2004) In vitro stimulation with WT1 peptide-loaded Epstein-Barr virus-positive B cells elicits high frequencies of WT1 peptidespecific T cells with in vitro and in vivo tumoricidal activity. Clin. Cancer Res. 10, 7207-7219.

48. Gao, L., Xue, S.A., Hasserjian, R., Cotter, F., Kaeda, J., Goldman, J.M., Dazzi, F., and Stauss, H.J. (2003) Human cytotoxic T lymphocytes specific for Wilms' tumor antigen-1 inhibit engraftment of leukemia-initiating stem cells in non-obese diabetic-severe combined immunodeficient recipients. Transplantation 75, 1429-1436.

49. Makita, M., Hiraki, A., Azuma, T., Tsuboi, A., Oka, Y., Sugiyama, H., Fujita, S., Tanimoto, M., Harada, M., and Yasukawa, M. (2002) Antilung cancer effect of WT1-specific cytotoxic T lymphocytes. Clin. Cancer Res. 8, 26262631.

50. Gaiger, A., Reese, V., Disis, M.L., and Cheever, M.A. (2000) Immunity to WT1 in the animal model and in patients with acute myeloid leukemia. Blood 96, 1480-1489.

51. Gaiger, A., Carter, L., Greinix, H., Carter, D., McNeill, P.D., Houghton, R.L., Cornellison, C.D., Vedvick, T.S., Skeiky, Y.A., and Cheever, M.A. (2001) WT1-specific serum antibodies in patients with leukemia. Clin. Cancer Res. 7, 761s-765s.

52. Elisseeva, O.A., Oka, Y., Tsuboi, A., Ogata, K., Wu, F., Kim, E.H., Soma, T., Tamaki, H., Kawakami, M., Oji, Y., Hosen, N., Kubota, T., Nakagawa, M., Yamagami, T., Hiraoka, A., Tsukaguchi, M., Udaka, K., Ogawa, H., Kishimoto, T., Nomura, T., and Sugiyama, H. (2002) Humoral immune responses against Wilms tumor gene WT1 
product in patients with hematopoietic malignancies. Blood 99, 3272-3279.

53. Wu, F., Oka, Y., Tsuboi, A., Elisseeva, O.A., Ogata, K., Nakajima, H., Fujiki, F., Masuda, T., Murakami, M., Yoshihara, S., Ikegame, K., Hosen, N., Kawakami, M., Nakagawa, M., Kubota, T., Soma, T., Yamagami, T., Tsukaguchi, M., Ogawa, H., Oji, Y., Hamaoka, T., Kawase, I., and Sugiyama, H. (2005) Th1-biased humoral immune responses against Wilms tumor gene WT1 product in the patients with hematopoietic malignancies. Leukemia 19, $268-274$.

54. Scheibenbogen, C., Letsch, A., Thiel, E., Schmittel, A., Mailaender, V., Baerwolf, S., Nagorsen, D., and Keilholz, U. (2002) CD8 T-cell responses to Wilms tumor gene product WT1 and proteinase 3 in patients with acute myeloid leukemia. Blood 100, 2132-2137.

55. Rezvani, K., Grube, M., Brenchley, J.M., Sconochia, G., Fujiwara, H., Price, D., Gostick, E., Yamada, K., Melenhorst, J., Childs, R., Hensel, N., Douek, D.C., and Barret, A.J. (2003) Functional leukemia-associated antigenspecific memory CD8 $+\mathrm{T}$ cells exist in healthy individuals and in patients with chronic myelogenous leukemia before and after stem cell transplantation. Blood 102, 2892-2900.

56. Rezvani, K., Brenchley, J.M., Price, D.A., Kilical, Y., Gostick, E., Sewell, A.K., Li, J., Mielke, S., Douek, D.C., and Barrett, A.J. (2005) T-cell responses directed against multiple HLA-A*0201-restricted epitopes derived from Wilms' tumor 1 protein in patients with leukemia and healthy donors: identification, quantification, and characterization. Clin. Cancer. Res. 11, 8799-8807.

57. Gillmore, R., Xue, S.A., Holler, A., Kaeda, J., Hadjiminas, D., Healy, V., Dina, R., Parry, S.C., Bellantuono, I., Ghani, Y., Coombes, R.C., Waxman, J., and Stauss, H.J. (2006) Detection of Wilms' tumor antigen--specific CTL in tumor-draining lymph nodes of patients with early breast cancer. Clin. Cancer. Res. 12, 34-42.

58. Oka, Y., Tsuboi, A., Taguchi, T., Osaki, T., Kyo, T., Nakajima, H., Elisseeva, O.A., Oji, Y., Kawakami, M., Ikegame, K., Hosen, N., Yoshihara, S., Wu, F., Fujiki, H., Murakami, M., Masuda, T., Nishida, S., Shirakata, T., Nakatsuka, S., Sasaki, A., Udaka, K., Dohy, H., Aozasa, K., Noguchi, S., Kawase, I., and Sugiyama, H. (2004) Induction of WT1 (Wilms' tumor gene)-specific cytotoxic T lymphocytes by WT1 peptide vaccine and the resultant cancer regression. Proc. Natl. Acad. Sci. U. S. A. 101, 13885-13890.

59. Tsuboi, A., Oka, Y., Ogawa, H., Elisseeva, O.A., Li, H., Kawasaki, K., Aozasa, K., Kishimoto, T., Udaka, K., and Sugiyama, H. (2000) Cytotoxic T-lymphocyte responses elicited to Wilms' tumor gene WT1 product by DNA vaccination. J. Clin. Immunol. 20, 195-202.

60. Nakajima, H., Kawasaki, K., Oka, Y., Tsuboi, A., Kawakami, M., Ikegame, K., Hoshida, Y., Fujiki, F., Nakano, A., Masuda, T., Wu, F., Taniguchi, Y., Yoshihara, S., Elisseeva, O.A., Oji, Y., Ogawa, H., Azuma, I., Kawase, I., Aozasa, K., and Sugiyama, H. (2004) WT1 peptide vaccination combined with BCG-CWS is more efficient for tumor eradication than WT1 peptide vaccination alone. Cancer Immunol. Immunother. 53, 617-624.

61. Yamamura, Y., Sakatani, M., Ogura, T., and Azuma, I. (1979) Adjuvant immunotherapy of lung cancer with BCG cell wall skeleton (BCG-CWS). Cancer 43, 1314-1319.

62. Ochiai, T., Sato, H., Hayashi, R., Asano, T., Sato, H., and Yamamura, Y. (1983) Postoperative adjuvant immunotherapy of gastric cancer with BCG-cell wall skeleton. 3- to 6-year follow up of a randomized clinical trial. Cancer Immunol. Immunother. 14, 167-171.

63. Hayashi, A. and Noda, A. (1996) Does the cell wall skeleton from Bacille Calmette-Guerin directly induce interferongamma, independent of interleukin-12? Jpn. J. Clin. Oncol. 26, 124-127.

64. Oka, Y., Tsuboi, A., Murakami, M., Hirai, M., Tominaga, N., Nakajima, H., Elisseeva, O.A., Masuda, T., Nakano, A., Kawakami, M., Oji, Y., Ikegame, K., Hosen, N., Udaka, K., Yasukawa, M., Ogawa, H., Kawase, I., and Sugiyama, H. (2003) Wilms tumor gene peptide-based immunotherapy for patients with overt leukemia from myelodysplastic syndrome (MDS) or MDS with myelofibrosis. Int. J. Hematol. 78, 56-61.

65. Tsuboi, A., Oka, Y., Osaki T., Kumagai, T., Tachibana, I., Hayashi, S., Murakami, M., Nakajima, H., Elisseeva, O.A., Wu, F., Masuda, T., Yasukawa, M., Oji, Y., Kawakami, M., Hosen, N., Ikegame, K., Yoshihara, S., Udaka, K., Nakatsuka, S., Aozasa, K., Kawase, I., and Sugiyama, H. (2004) WT1 peptide-based immunotherapy for patients with lung cancer: report of two cases. Microbiol. Immunol. 48, 175-184.

66. Wang, F., Bade, E., Kuniyoshi, C., Spears, L., Jeffery, G., Marty, V., Groshen, S., and Weber, J. (1999) Phase I trial of a MART-1 peptide vaccine with incomplete Freund's adjuvant for resected high-risk melanoma. Clin. Cancer Res. 5, 2756-2765.

67. Pullarkat, V., Lee, P.P., Scotland, R., Rubio, V., Groshen, S., Gee, C., Lau, R., Snively, J., Sian, S., Woulfe, S.L., Wolfe, R.A., and Weber, J.S. (2003) A phase I trial of SD-9427 (progenipoietin) with a multipeptide vaccine for resected metastatic melanoma. Clin. Cancer Res. 9, 1301-1312.

68. Nilsson, L., Astrand-Grundstrom, I., Arvidsson, I., Jacobsson, B., Hellstrom-Lindberg, E., Hast, R., and Jacobsen, S.E. (2000) Isolation and characterization of hematopoietic progenitor/stem cells in 5q-deleted myelodysplastic syndromes: evidence for involvement at the hematopoietic stem cell level. Blood 96, 2012-2021.

69. Mailaender, V., Scheibenbogen, C., Thiel, E., Letsch, A., Blau, I. W., and Keilholz, U. (2004) Complete remission in a patient with recurrent acute myeloid leukemia induced by vaccination with WT1 peptide in the absence of hematological or renal toxicity. Leukemia 18, 165-166.

70. Morita, S., Oka, Y., Tsuboi, A., Kawakami, M., Maruno, M., Izumoto, S., Osaki, T., Taguchi, T., Ueda, T., Myoui, A., Nishida, S., Shirakata, T., Ohno, S., Oji, Y., Aozasa, K., Hatazawa, J., Udaka, K., Yoshikawa, H., Yoshimine, T., Noguchi, S., Kawase, I., Nakatsuka, S., Sugiyama, H., and Sakamoto, J. (2006) A phase I/II trial of a WT1 (Wilms' 
tumor gene) peptide vaccine in patients with solid malignancy: safety assessment based on the phase I data. Jpn. J. Clin. Oncol. 36, 231-236.

71. Drakos, E., Rassidakis, G.Z., Tsioli, P., Lai, R., Jones, D., and Medeiros, L.J. (2005) Differential expression of WT1 gene product in non-Hodgkin lymphomas. Appl. Immunohistochem. Mol. Morphol. 13, 132-137.

72. Azuma, T., Otsuki, T., Kuzushima, K., Froelich, C.J., Fujita, S., and Yasukawa, M. (2004) Myeloma cells are highly sensitive to the granule exocytosis pathway mediated by WT1-specific cytotoxic T lymphocytes. Clin. Cancer Res. 10, 7402-7412.

73. Knights, A.J., Zaniou, A., Rees, R.C., Pawelec, G., and Muller, L. (2002) Prediction of an HLA-DR-binding peptide derived from Wilms' tumour 1 protein and demonstration of in vitro immunogenicity of WT1(124-138)-pulsed dendritic cells generated according to an optimised protocol. Cancer Immunol. Immunother. 51, 271-281.

74. Muller, L., Knights, A., and Pawelec, G. (2003) Synthetic peptides derived from the Wilms' tumor 1 protein sensitize human T lymphocytes to recognize chronic myelogenous leukemia cells. Hematol J. 4, 57-66.

75. Kobayashi, H., Nagato, T., Aoki, N., Sato, K., Kimura, S., Tateno, M., and Celis, E. (2006) Defining MHC class II T helper epitopes for WT1 tumor antigen. Cancer Immunol. Immunother. 55, 850-860.

76. Fujiki, F., Oka, Y., Tsuboi, A., Kawakami, M., Kawakatsu, M., Nakajima, H., Elisseeva, O.A., Harada, Y., Ito, K., Li, Z., Tatsumi, N., Sakaguchi, N., Fujioka, T., Masuda, T., Yasukawa, M., Udaka, K., Kawase, I., Oji, Y., and Sugiyama, H. (2007) Identification and characterization of a WT1 (Wilms tumor hene) protein-derived HLADRB $1 * 0405$-restricted 16-mer helper peptide that promotes the induction and activation of WT1-specific cytotoxic T lymphocytes. J. Immunother. 30(3), 282-293.

77. Noguchi, M., Itoh, K., Suekane, S., Yao, A., Suetsugu, N., Katagiri, K., Yamada, A., Yamana, H., and Noda, S. (2004) Phase I trial of patient-oriented vaccination in HLA-A2-positive patients with metastatic hormone-refractory prostate cancer. Cancer Sci. 95, 77-84.

78. Bocchia, M., Gentili, S., Abruzzese, E., Fanelli, A., Iiuliano, F., Tabilio, A., Amabile, M., Forconi, F., Gozzetti, A., Raspadori, D., Amadori, S., and Lauria, F. (2005) Effect of a p210 multipeptide vaccine associated with imatinib or interferon in patients with chronic myeloid leukaemia and persistent residual disease: a multicentre observational trial. Lancet 365, 657-662.

79. Ercolini, A.M., Ladle, B.H., Manning, E.A., Pfannenstiel, L.W., Armstrong, T.D., Machiels, J.P., Bieler, J.G., Emens, L.A., Reilly, R.T., and Jaffee, E.M. (2005) Recruitment of latent pools of high-avidity CD8(+) T cells to the antitumor immune response. J. Exp. Med. 201, 1591-1602.

80. Chong, G. and Mors, M.A. (2005) Combining cancer vaccines with chemotherapy. Expert Opin. Pharmacother. 6, 2813-2820.

81. Suzuki, K., Kapoor, V., Jassar, A.S., Kaiser, L.R., and Albelda, S.M. (2005) Gemcitabine selectively eliminates slpenic Gr-1+/CD11b+ myeloid suppressor cells in tumor-bearing animals and enhances antitumor immune activity. Clin. Cancer Res. 11, 6713-6721.

82. Kawakami, M., Oka, Y., Tsuboi, A., Harada, Y., Elisseeva, O.A., Furukawa, Y., Tsukaguchi, M., Shirakata, T., Nishida, S., Nakajima, H., Morita, S., Sakamato, J., Kawase, I., Oji, Y., and Sugiyama, H. (2007) Clinical and immunological responses to the vaccination with very low dose $(5 . \mu \mathrm{g} /$ body $)$ of WT1 peptide in a patient with chronic myelomonocytic leukemia. Int. J. Hematol., in press.

83. Oka, Y., Tsuboi, A., Kawakami, M., Elisseeva, O.A., Nakajima, H., Udaka, K., Kawase, I., and Sugiyama, H. (2006) Development of WT1 peptide cancer vaccine against hematopoietic malignancies and solid cancers. Curr. Med. Chem. 13, 2345-2352.

84. Hori, A., Kami, M., Kim, S.-W., Murashige, N., Sakiyama, M., Kojima, R., Hamaki, T., Makimoto, A., Miyakoshi, S., Masuo, S., Taniguchi, S., Kunitoh, H., and Takaue, Y. (2004) Urgent need for a validated tumor response evaluation system for use in immunotherapy. Bone Marrow Transplant. 33, 255-256.

\section{This article should be cited as follows:}

Oka, Y., Tsuboi, A., Elisseeva, O.A., Nakajima, H., Fujiki, F., Kawakami, M., Shirakata, T., Nishida, S., Hosen, N., Oji, Y., Kawase, I., and Sugiyama, H. (2007) WT1 peptide cancer vaccine for patients with hematopoietic malignancies and solid cancers. TheScientificWorldJOURNAL 7, 649-665. DOI 10.1100/tsw.2007.119. 

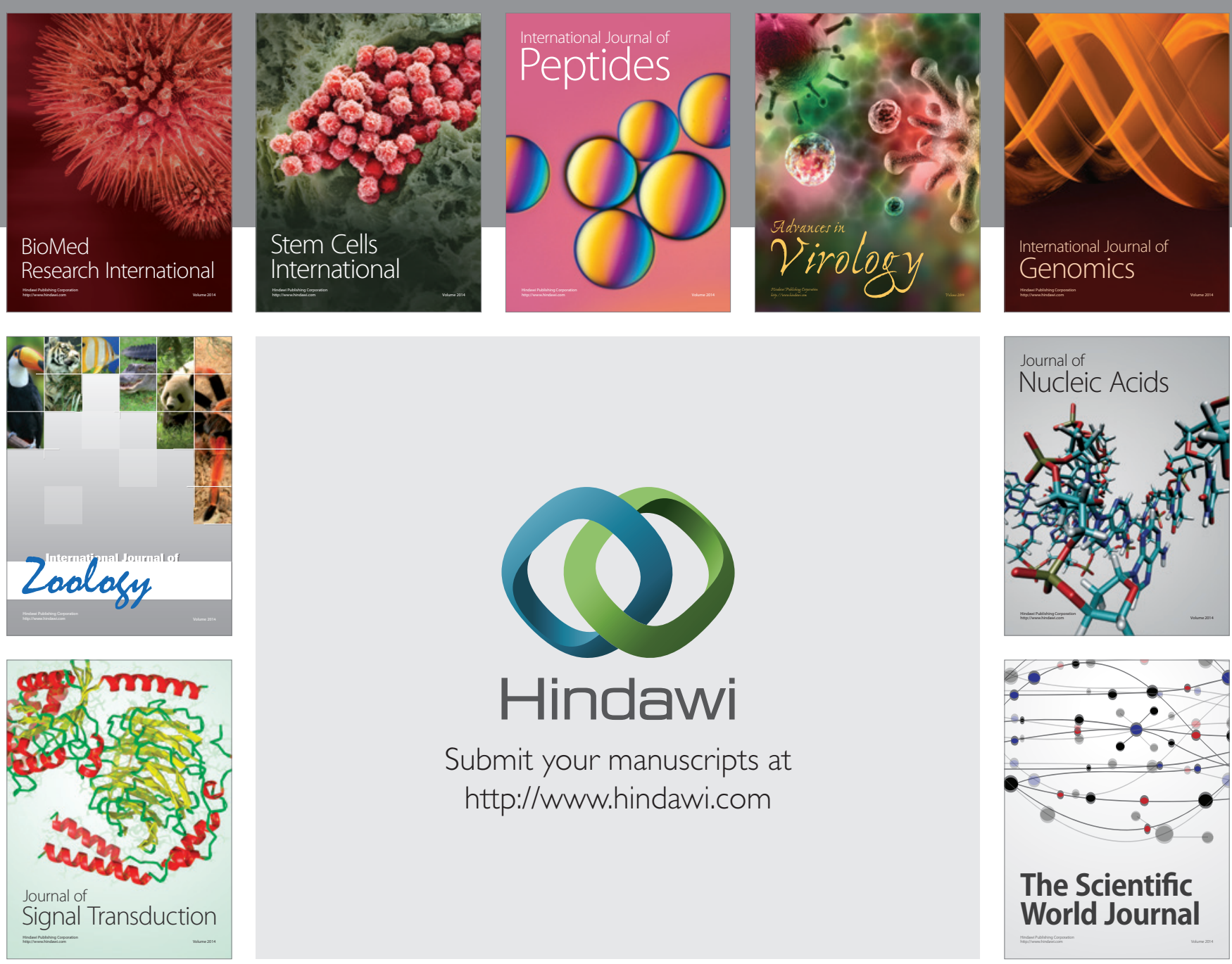

Submit your manuscripts at

http://www.hindawi.com
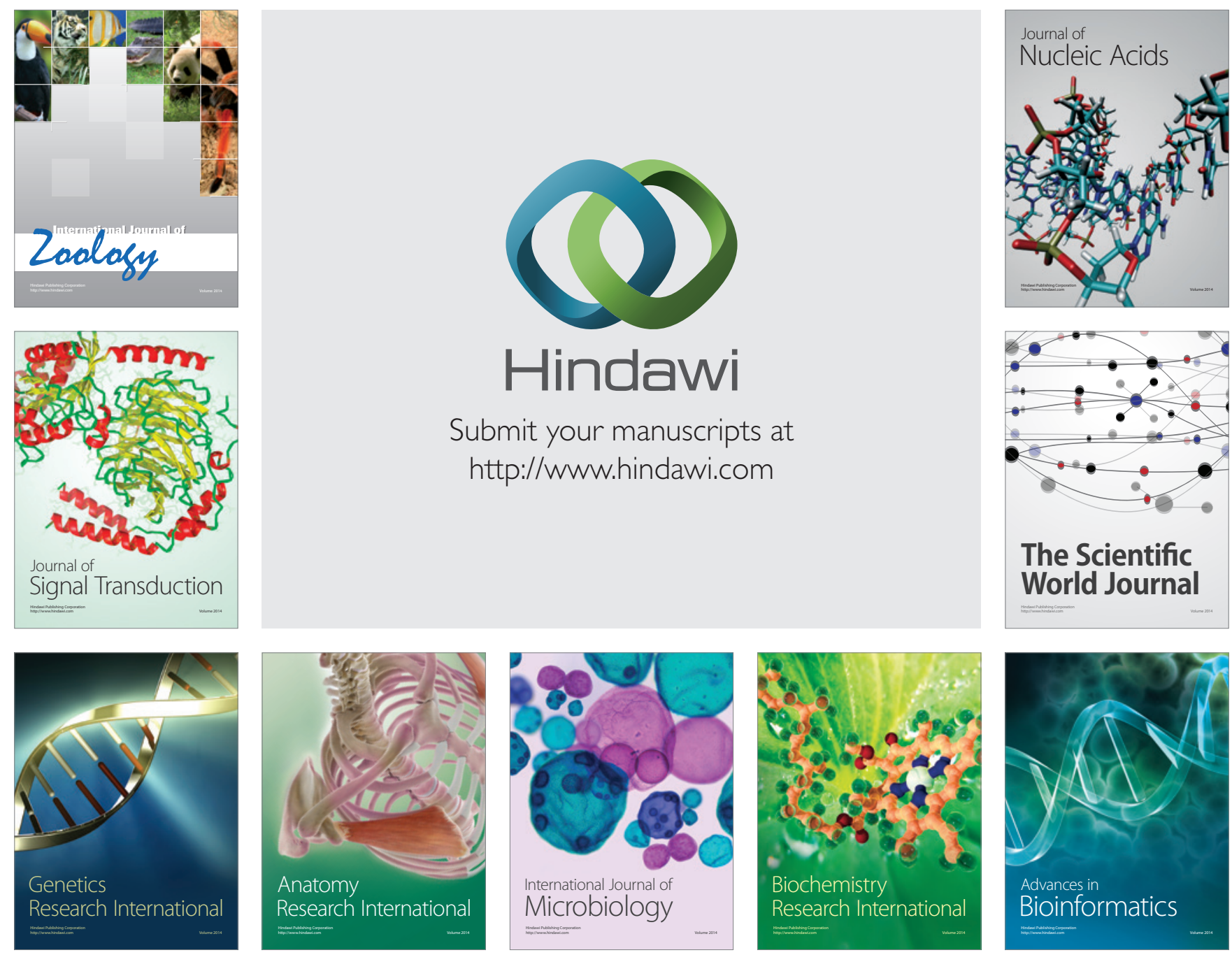

The Scientific World Journal
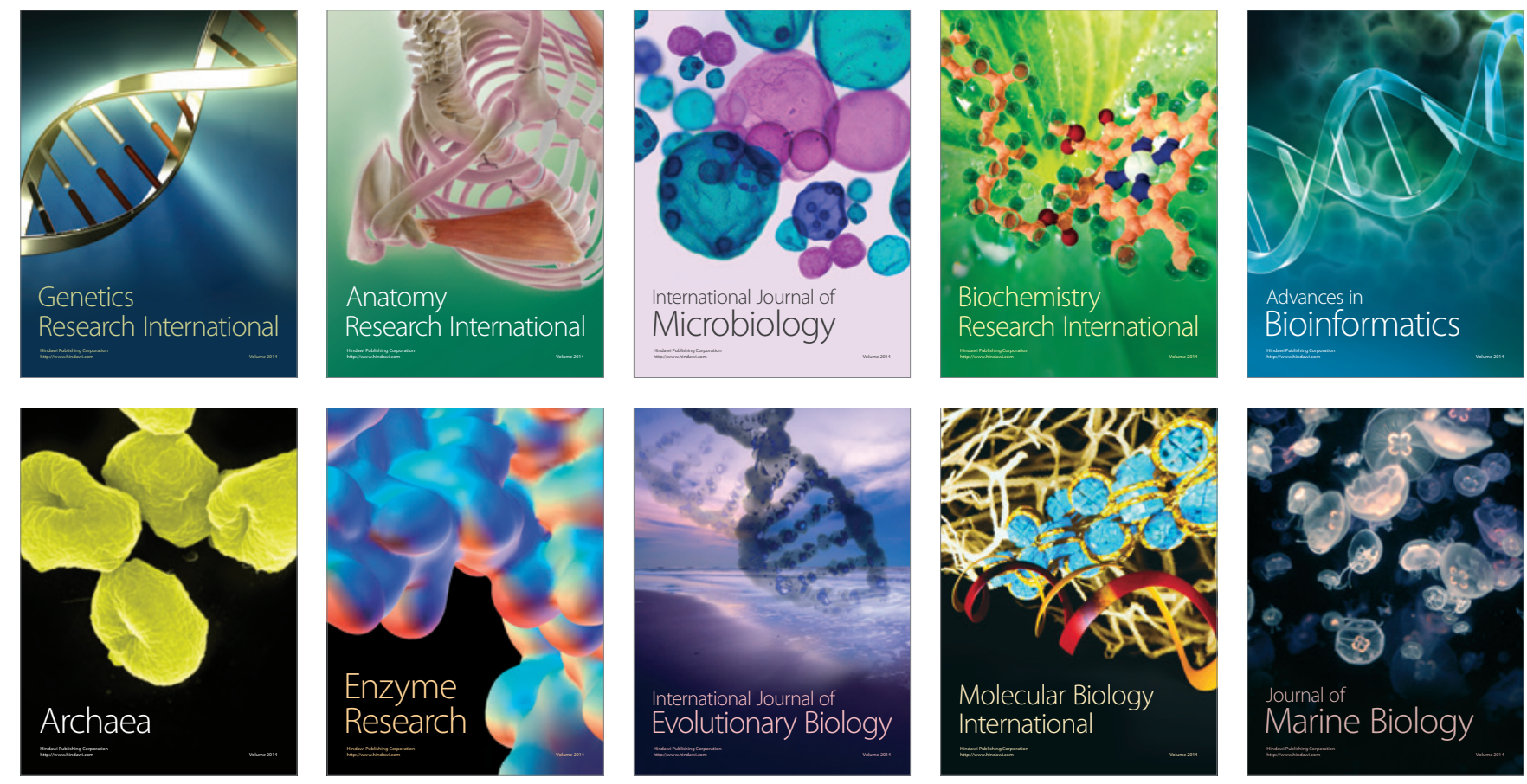